International Journal of Economics, Business and Accounting Research (IJEBAR)

Peer Reviewed - International Journal

Vol-5, Issue-1, 2021 (IJEBAR)

E-ISSN: 2614-1280 P-ISSN 2622-4771

http://jurnal.stie-aas.ac.id/index.php/IJEBAR

\title{
CREATING CUSTOMER RETENTION THROUGH FACILITY, COMPLAINT HANDLING, TRUST, COMPANY IMAGE AND CUSTOMER INCENTIVES AT BMT AMANAH UMMAH KARTASURA, SUKOHARJO
}

\author{
Istiatin, Fithri Marwati
}

Faculty of Economics, Batik Islamic University of Surakarta, Indonesia E-mail : istiatinumi@gmail.com

Abstract: The purpose of this study was to analyze and test the effect of Company Image, Customer Incentives, Trust, Complaints Handling, and Facility on Costumer Retention at BMT Amanah Ummah Kartasura. The research method applied in this study was a quantitative descriptive research design. This study used a population of 1,500 respondents. In determining the sample size, this study used the Slovin formula. After calculating using the Slovin formula, the number of samples in this study was 100 respondents. The sampling technique was carried out using incidental sampling. The data collection was done using a questionnaire. The data analysis technique in this study was statistical analysis consists of multiple linear regression test, $F$ test, $t$ test and the coefficient of determination. The results showed that the Company Image, Customer Incentives, Trust, Complaint Handling, and Facility simultaneously had a significant effect on Customer Retention at BMT Amanah Ummah Kartasura. Partially, it was found that Company Image and Customer Incentives do not have a positive and significant effect on Customer Retention at BMT Amanah Ummah in Kartasura. Meanwhile, Trust, Complaint Handling, and Facility have a positive and significant effect on Customer Retention at BMT Amanah Ummah in Kartasura. The coefficient of determination or the contribution of the variables of Company Image, Customer Incentives, Trust, Complaint Handling, and Facility on Customer Retention at BMT Amanah Ummah Kartasura was 43.1\%. This study suggested that BMT Amanah Ummah should continue to improve and pay attention to the factors that affect the Customer Retention, such as Company Image, Customer Incentives, Trust, Complaint Handling, and Facility. One of the important elements of banking strategy in today's increasingly competitive environment is customer retention. In this case, to identify and improve upon factors that can limit customer's defection is very necessary.

Keywords: Customer Retention, Trust, Complaint Handling, Facility, Company Image, BMT Amanah Ummah. 


\section{Introduction}

Currently, Indonesia has become of the countries that show a significant development of the application of the Islamic economy. The social and the Islamic microfinance sector is arguably an important and superior aspect of the development of the Islamic economy in Indonesia. The development of the sharia sector in Indonesia is certainly supported by the Muslim population, which is the largest population in Indonesia and the largest in the world. According to The World Giving Index, Indonesia has become one of the most generous countries in donating cash donations; even the practice of managing Islamic social funds through Islamic philanthropic institutions and mosques has been very widespread and has become an important part of the development and creation of prosperity in Indonesia. On the other hand, the Islamic microfinance sector also continues to grow through cooperatives and sharia microfinance institutions, particularly BMT, a pure Islamic microfinance institution born with Indonesian uniqueness that has two functions, namely the amil function (Baitul Maal) and the financing function (Baitut Tamwil).

As a Sharia Microfinance Institution (LKMS) or sharia micro finance in the form of a cooperative legal entity, the development of BMTs in Indonesia is quite rapid and encouraging, when viewed in terms of quantity and annual growth. In 2020, nationally stated that the number of BMT as many as 5400 units reached assets of 4.7 Trillion with total financing of 3.6 Trillion and total deposits of 2.1 Trillion (KNKS, 2020). The increasing number of Islamic financial institutions, making all financial institutions must improve the quality of their services. In this case, with the quality that is maintained as well as the comfort and variety of products offered, it is expected that it will continue to attract the interest of BMT members.

Many different strategies are conducted by every Baitul Maal Wat Tamwil (BMT) in winning competition in the market. The growing member loyalty is a demand that must be done by BMT, since by maintaining the loyalty of BMT members, the existence of BMT will be maintained. Creating and maintaining loyal members is the main thing that must be done by every organization. In this case is Baitul Maal Wat Tamwil (BMT), especially the customers loyalty, where in collecting its funds, BMT must obtain good trust from its members or customers. If observed, people are smarter and more selective in entrusting the right financial institutions to collect their funds. Aside from the trust of members, member satisfaction is also a determinant of member loyalty.

In an effort to retain customers, companies need to strive to create customer loyalty. Nevertheless, companies need to realize that loyalty alone is not enough to guarantee the survival of the company, since loyalty does not have much influence on sales and profit figures. There needs to be concrete action as evidence that customers are truly loyal to the company, namely customer retention. Therefore, many companies have concluded that they are increasingly adapting customer retention techniques to improve company performance. In this case, BMT Amanah Ummah as one of a sharia financial institution must be able to compete competitively. One of the alternatives of marketing strategy carried out by BMT is to 
create customer retention to improve quality, service performance and expand market segments (Krismawintari and Kurniawati, 2018). Schiffman and Wisenblit (2015) state that customer retention is related to changing individual customer transactions into long-term customer relationships by making these customers stay with one company rather than switching companies.

Customer retention is a process that makes customers loyal to a certain company and makes repeat purchases or reuses services from that company. Retaining customers is much more profitable for the company than finding new customers (Danish and Humayon, 2015).

Increasing customer retention requires an understanding of the factors that can create it. One of the factors is the formation of customer retention by providing incentives from banks that are very attractive to customers (Parno, Nursalim and Khairi, 2018). The incentives provided to customers aim to encourage increased transactions (Noviandari, Retnowati and Firmanzah, 2012). The results showed that incentives can affect customer retention. The company links customer satisfaction measures, customer retention and new customers in providing incentives (Kaplan and Norton 2001 in Hafif, 2014).

Customer trust is one of the important factors in influencing the progress of the company which certainly provides comfort to its customers. Trust arises from a long process where both parties trust each other (Widiartanto, Farida and Sulistiani, 2015). Heriyadi, Listiana and Lay (2018) state that trust has a positive and significant effect on customer retention. When consumers trust the company, consumers will continue to be repeat customers in the long run. Lompoliu (2019) found that the most dominant factor in influencing the customer retention is the customer trust.

Complain Handling is an effort to maintain good relations with customers. The ability of company to avoid service failures and complaints tends to have high expectations of overall customer satisfaction (Ndubisi, 2012). Complaints occur due to the customer dissatisfaction with the services provided by the company, if this continues; it will have a negative impact on the company (Heriyadi, Listiana and Lay, 2018). Handaruwati (2020) found that conflict handling has a partial and simultaneous effect on consumer retention.

The definition of facilities is anything in the form of objects or money that can facilitate and facilitate the implementation of a certain business (Sam, 2008). Research by Nurcahyo (2017) found that facilities have a positive influence on customer loyalty. Facilities have a significant and direct effect on customer satisfaction. This shows that bad facilities will lead to bad customer satisfaction. This means that better facilities will also increase the level of customer satisfaction. Kumar (2020), shows that the facility factor has a significant effect on customer loyalty and customer satisfaction.

In carrying out its business activities specifically for marketing activities, each company has a goal, which is to increase sales for the company, one of which is by maintaining their image in the eyes of consumers, especially for customers who place their loyalty to the company, feeling satisfied or not consumers occur after have experience with a company that begins with a purchase decision, therefore, it can be concluded that the existence of a good 
image is important as an internal resource object in determining its relationship with the company. Almassawa (2018) found that company image shows a positive effect on customer loyalty. A research conducted by Subagiyo (2019) also shows that company image has a significant effect on customer satisfaction, service quality has a significant effect on customer satisfaction and distribution channels have a significant effect on customer satisfaction.

This study was conducted at KSPPS BMT Amanah Ummah Kartasura which is located at Jl. Slamet Riyadi 292 Gumpang, Kartasura, Sukoharjo. It is engaged in sharia financial institutions. KJKS BMT Amanah Ummah Kartasura is a sharia microfinance institution that is run on the principles of financing, investment, and savings according to the profit sharing (sharia) procedures.

Numerous studies confirm the importance of customer retention strategies. Comprehensive research conducted by Bain \& Company in Tjiptono's (2015) book on a number of service industries in America found that customer loyalty is positively related to company profitability. To prosper with the growing competition in the business world, customer retention is very essential for a business. An organization or institution has to continuously adapt better strategies and more specifically improved mechanisms to eventually seize to the accustomed clients of the organization, thus attracts potential customers in the future, especially in the locality where banking industry such as BMT Amanah Ummah as a sharia financial institution was generously operating and growing utmost. Consequently, the identification on how these customers can be influenced through the different factors to be retained in one's business such as, company image, complaint handling, customer incentives, trust, and facility were imperative to achieve these aspirations. Based on this background, the researcher is intended to conduct this study to determine the effect of variables of trust, complaint handling, customer incentives, facility, and company image simultaneously and partially on customer retention at BMT Amanah Ummah Kartasura.

This can enhances the organizations' performance as well as their customer relationship for profitability of their business and thus, provides information on how banks will be more competitive amidst competitors in the locality. Implementing customer retention can increase sales figures and company revenues. For every business, one of the things that is certain is that managing customers is an important step that must be done with full planning.

\section{Literature Review}

\subsection{Customer Retention}

According to Farquhar (2005) in Zangmo et al (2015) states that customer retention is how to increase sales by satisfying and serving consumers, so that they keep coming back. According to Singh and Khan (2012), customer retention is the activity of a sales organization in an effort to reduce failed customers. Customer retention begins when the company first makes contact with customers until the company can establish long-term relationships with customers. Schiffman and Wisenblit (2015) state that customer retention is related to changing individual customer transactions into long-term customer relationships by making these 
customers stay with one company rather than moving companies. According to Alfansi (2016: 244), customer retention is "an effort to retain customers an important part of relationshipbased marketing development". For a company they do not only want new customers but they also need to retain customers since this can increase the business.

\subsection{Trust}

Trust held by customers is an intangible asset that can be obtained by the company (Matzler, Krauter, and Bidmon, 2006). Zboja and Voorhees, 2006 state that trust from within the customer is indicated by the belief of a customer in the reliability and integrity of the company when selling a product or service. Trust is the attitude of consumer trust in a product. Trust relates to experience and proof of what is obtained from a particular brand. Trust is a stage in the formation of brand equity (Mooreman et al, 1992: 315). Fukuyama defines trust as, "the expectations that arise in a community related to norms, honesty, cooperation, and other norms" (Fukuyama, 1995: 26). Morgan and Hunt say that trust is a hypothetical tool in building commitment (Morgan and Hunt, 1994: 16).

\subsection{Complaint Handling}

According to Suchaeri (2012: 67), complaint handling (customer complaints) as a very valuable source of information for evaluating company performance improvements, opening customer complaints and being an opportunity for companies to immediately fix problems. According to Tjiptono (2011: 164), good complaint handling provides an opportunity to turn dissatisfied customers into satisfied customers or even lasting customers. Complaint handling is a source of positive input for companies in improving themselves to provide services to their customers. The ability of company to avoid service failures and complaints tends to have a big bearing on overall customer satisfaction (Ndubisi, 2012). Complaint handling is defined as the ability of company to prevent potential complaints, resolve complaints in real time before they become problems and discuss solutions openly when problems arise (Ndubisi, 2007; Ningtyas \& Rachmad, 2011). Complaint handling occurs due to the customer dissatisfaction with the services provided by the company, if this continues, it will have a negative impact on the company.

\subsection{Customer Incentives}

Kotler (2009: 8) defines that marketing is the main activity carried out by the company in maintaining the company's survival, developing to get benefits and long-term loyalty from customers. Kotler and Keller (2009: 23) one of the strategies carried out by companies by implementing customer loyalty programs, efforts to retain customers through providing incentives or rewards to customers. According to Kotler (2008: 219), providing incentives to customers is one of the ways to create loyalty with the company, which aims to maintain and strengthen customer relationships. It is evident that consumer incentives create relationships and drive brand loyalty. A well-designed consumer incentive program attracts new customers and retains existing ones, which results in the increased of sales.

\subsection{Facility}

According to Sam (2012), facilities are everything in the form of objects or money that 
can facilitate and facilitate the implementation of a certain business. Facilities can also be interpreted as the facilities and infrastructure available in the environment and within the company office, in this case it is intended to provide maximum service so that consumers or users feel comfortable and satisfied. Facilities are the main supporting factors in the activities of a product. Facilities are an important aspect for services. Facilities are physical representations of services, which are usually the equipment used. According to Tjiptono (2007), services are intangible; therefore consumers often rely on tangible cues or physical evidence in evaluating a service before buying it and assessing its satisfaction and after consumption. Physical evidence includes physical facilities (servicescape) and other tangible elements, which help consumers to understand and evaluate services that are intangible. In general, physical evidence includes the physical facilities of the Servicescape organization (such as parking lots, waiting rooms, equipment, air quality/ temperature) and other forms of physical communication (such as employee clothing and uniforms, brochures, internet sites, and so on). In several types of services (such as hospitals, hotels, airlines), many service providers make use of communication via their physical evidence. Meanwhile, for other types of services (such as insurance and express deposit services), physical evidence communication is relatively limited. The physical facilities of the company essentially "wrap" or "package" the services offered and communicate an external image of what is in it to consumers.

\subsection{Company Image}

Image can be measured through a person's views, impressions, responses with the aim of knowing exactly what is on the mind of each individual about an object, how they understand it and what they like or not about that object. Where an image of an object can be different depending on individual perceptions, even the image of one object can be the same for everyone. Jefkins in Soemirat and Ardianto, (2007), defines company image as "the image of an organization as a whole, therefore, it is not only an image of its products and services. This company image is shaped by many things. Positive things that can improve the image of a company include the history or profile of a glorious company, the successes in the financial sector that it has achieved, export success, good industrial relations, reputation as a large number of job creators, willingness share social responsibility, and commitment to conduct research, and so on".

\section{Research Method}

In this study, the research method applied was a descriptive quantitative. The research approach used by this study was a quantitative approach since it used numbers, starting from data collection, interpretation of the data, and the presentation of the results (Arikunto, 2012). The data analysis technique used in this study was statistical analysis which explains and provides an overview of the object under study and through the sample data collected. This research was conducted from October 2019 to January 2020. The population in this study was 1,500 respondents. To determine the sample size in this study, the researcher used the Slovin formula. The results of calculation showed that 100 respondents were suitable to be used in 
this study. Meanwhile, a non-probability sampling technique was used as a sampling technique. It is an incidental sampling, a sampling technique based on chance, that is, anyone who happens to meet the researcher can be sampled, if seen by someone who happens to be considered a suitable source of data (Sugiyono, 2016).

\section{Results and Discussion}

The following are the results of the statistical analysis for hypothesis testing and discussion of the statistical analysis testing.

\subsection{Data Analysis}

\subsubsection{Classical Assumption Test}

Before testing the multiple linear regression analysis on the hypothesis of the study, it is necessary to first test the classical assumptions of the data to be processed. Based on the test results, all classical deviations from the research data can be explained as follows:

a. Normality Test

This test is used to determine whether each variable has a normal distribution or not. The normality test in this study used the Kolgomorov-Smirnov statistics. The criteria used is through the Asymp value. Sig (2-Tailed). The measurement is by comparing the Asymp value. Sig (2- Tailed) with a specified alpha value of 5\%, therefore, if the value of Asymp. Sig (2-tailed) $>0.05$, it can be concluded that the data comes from a normally distributed population. The results of the normality test are presented in the following table:

Tabel 1. Results of Normality Test

\begin{tabular}{|c|c|c|c|}
\hline Kolmogorov-Smirnov $Z$ & Sig & Limit & Interpretation \\
\hline 0,744 & 0,637 & 0,05 & Normal \\
\hline
\end{tabular}

Source: Data processed 2020.

Based on the results of the Kolomorov Smirnov test above, it shows that the residual data obtained follows a normal distribution, based on the output results indicate that the Kolmogorov-Smirnov value is significant at $0.637>0.05$ and $0.744>0.05$. Thus, the data residuals are normally distributed and the regression model has met the normality assumption. b. Multicollinearity Test

Multicollierity test aims to test whether a regression model found a correlation between the independent variables. Multicollinearity can be detected by looking at the tolerance value and Variance Inflation Factor (VIF). The results of the analysis on the multicollierity test of this study are as follows:

Table 2. Results of Multicollinearity Test

\begin{tabular}{|c|c|c|c|}
\hline Variables & Tol & VIF & Interpretation \\
\hline Company image & 0,959 & 1,043 & $\begin{array}{c}\text { No } \\
\text { Multicollinearity }\end{array}$ \\
\hline Customer incentives & 0,707 & 1,414 & $\begin{array}{c}\text { No } \\
\text { Multicollinearity }\end{array}$ \\
\hline
\end{tabular}


International Journal of Economics, Business and Accounting Research (IJEBAR)

Peer Reviewed - International Journal

Vol-5, Issue-1, 2021 (IJEBAR)

E-ISSN: 2614-1280 P-ISSN 2622-4771

http://jurnal.stie-aas.ac.id/index.php/IJEBAR

\begin{tabular}{|c|c|c|c|}
\hline Trust & 0,922 & 1,085 & $\begin{array}{c}\text { No } \\
\text { Multicollinearity }\end{array}$ \\
\hline Complaint Handling & 0,939 & 1,064 & $\begin{array}{c}\text { No } \\
\text { Multicollinearity }\end{array}$ \\
\hline Facility & 0,740 & 1,351 & $\begin{array}{c}\text { No } \\
\text { Multicollinearity }\end{array}$ \\
\hline
\end{tabular}

Source: Data processed 2020

The above table shows the results of the multicollinearity test conducted in this study. It can be seen that the variance inflation factor (VIF) value of all variables in this study is less than 10; therefore, it can be assumed that there is no multicollinearity between the independent variables in the regression model.

c. Heteroscedasticity Test

The heteroscedasticity test aims to test whether the regression model is unequal variance. The results of the Heterokedacity statistical test obtained in this study are as follows:

Table 3. Results of Glejser Heteroscedasticity Test

\begin{tabular}{|c|c|c|c|}
\hline Variables & Sig & Limit & Interpretation \\
\hline Company image & 0,48 & $>0,05$ & $\begin{array}{c}\text { Heteroscedasticity } \\
\text { does not occur }\end{array}$ \\
\hline Customer incentives & 0,838 & $>0,05$ & $\begin{array}{c}\text { Heteroscedasticity } \\
\text { does not occur }\end{array}$ \\
\hline Trust & 0,192 & $>0,05$ & $\begin{array}{c}\text { Heteroscedasticity } \\
\text { does not occur }\end{array}$ \\
\hline Complaint Handling & 0,887 & $>0,05$ & $\begin{array}{c}\text { Heteroscedasticity } \\
\text { does not occur }\end{array}$ \\
\hline Facility & 0,604 & $>0,05$ & $\begin{array}{c}\text { Heteroscedasticity } \\
\text { does not occur }\end{array}$ \\
\hline
\end{tabular}

Source: Data processed 2020

As can be seen in the above table, the variables of Corporate Image, Customer Incentives, Trust, Complaint Handling, and Facility obtained a tolerance value $>0.10$ and a VIF value $<0.10$. Therefore, heteroscedasticity does not occur in the five variables.

\subsection{Hypothesis Testing}

The hypothesis is a temporary answer to the formulated problem. Therefore, the provisional answer must be tested empirically. Hypothesis testing in this study was carried out using multiple regression techniques (Multiple Linear Regression).

\subsubsection{Multiple Linear Regression Analysis}

In this study, hypothesis testing was carried out using Multiple Linear Regression which will be tested empirically to find a functional relationship between two or more independent variables and the dependent variable, or to predict two or more independent 
variables on the dependent variable. The results of multiple linear tests in this study can be seen in the following table:

Table 4. Results of Multiple Linear Regression Analysis

\begin{tabular}{|l|c|c|c|l|}
\hline \multicolumn{1}{|c|}{ Variables } & $\beta$ & t-count & Sig & \multicolumn{1}{|c|}{ Interpretation } \\
\hline Company image & 0,118 & 1,740 & 0,173 & Not significant \\
\hline Customer incentives & 0,081 & 0,953 & 0,085 & Not significant \\
\hline Trust & 0,553 & 6,403 & 0,000 & Significant \\
\hline Complain Handling & 0,259 & 2,890 & 0,005 & Significant \\
\hline Facility & 0,220 & 2,135 & 0,035 & Significant \\
\hline Constanta & $-4,210$ & \multicolumn{4}{|l}{} \\
\hline
\end{tabular}

Source: Data processed 2020

The above table shows the results of the coefficients based on Multiple Regression Analysis. It can be developed by using a multiple linear regression equation model as follows:

$$
Y=-4,210+0,118 X_{1}+0,081 X_{2}+0,553 X_{3}+0,259 X_{4}+0,220 X_{5}+e
$$

Interpretation:

a. A constant of $-4,210$ means that if the Company Image, Customer Incentives, Trust, Complaint Handling, and Facility do not exist, the increase in customer retention is $-4,210$.

b. The X1 regression coefficient is 0.118 , which means that each increase of one unit of company image will increase customer retention at BMT Amanah Ummah by 0.118. And vice versa, every decrease of one unit of Company Image, will decrease customer retention by 0.118 , assuming that the constant value is constant.

c. The X2 regression coefficient is 0.081 , which means that every increase of one unit of Customer Incentives will increase customer retention at BMT Amanah Ummah by 0.081. And vice versa, every decrease of one Customer Incentive unit, will decrease customer retention by 0.081 , assuming that the constant value is constant.

d. The X3 regression coefficient of 0.553 , means that every increase of one unit of trust will increase customer retention at BMT Amanah Ummah by 0.553. And conversely, every decrease of one unit of trust, will decrease customer retention by 0.553 , assuming that the constant value is constant.

e. The X4 regression coefficient is 0.259 , means that each increase of one Complaint Handling unit will increase customer retention at BMT Amanah Ummah by 0.259. And vice versa, every decrease of one Complaint Handling unit, will decrease customer retention by 0.259 , assuming that the constant value is constant.

f. The X5 regression coefficient of 0.220 means that each increase of one facility unit will increase customer retention at BMT Amanah Ummah by 0.220. And vice versa, every decrease of one facility unit, will decrease customer retention by 0.220 , assuming that the constant value is constant. 


\subsubsection{Coefficient of determination $\left(R^{2}\right)$ Analysis}

The coefficient of determination (R2) measures how far the ability of model to explain variations in the variable customer retention. The value of the coefficient of determination is between 0 and 1 . The value of $\mathrm{R} 2$ which is close to one means that the independent variable of the study provides almost all the information needed to predict variations in the customer retention variable. From the analysis results, obtained the correlation coefficient (R) of 0.431 . This means that the relationship between the independent variables and the dependent variable is $43.1 \%$, and the remaining $56.9 \%$ can be influenced by other factors that are not tested in this study.

\subsubsection{Simultaneous Significance Analysis (Test Statistic F)}

The $\mathrm{F}$ test shows whether all the independent variables have a joint influence on the dependent variable. Based on the analysis, it is obtained that the F count is 16,001 with a probability of 0,000 , which is below 0,000 . This shows that all independent variables, Company Image, Customer Incentives, Trust, Complaint Handling, and Facility have a significant effect simultaneously (together) on Customer Retention.

\subsubsection{Significance Test of Individual Parameters (t Statistical Test)}

The $t$ test is used to determine the effect of partially independent variables on the dependent variable. This test is to compare the probability value or p-value (sig-t) with a significance level of 0.05 . If the p-value is smaller than 0.05 then $\mathrm{Ha}$ is accepted, and vice versa if the p-value is greater than 0.05 then $\mathrm{Ha}$ is rejected. The results of the analysis on the partial t test in this study are as follows:

1) The $t$ test results on the Company Image variable showed t count of 1.740 with a probability of 0.173 , which value is above $0.050 .173>0.05$. Thus, $\mathrm{H} 1$ is rejected, which means that Company Image has no significant positive effect on Customer Retention.

2) The results of the $t$ test on the Customer Incentive variable showed t count of 0.953 with a probability of 0.085 whose value is above $0.050 .085>0.05$. Thus, $\mathrm{H} 2$ is rejected, which means that Customer Incentives has no significant positive effect on Customer Retention.

3) The results of the $t$ test on the Trust variable showed t count of 6.409 with a probability of 0.000 , where the value is below $0.050 .000<0.05$. Thus, $\mathrm{H} 3$ is accepted, which means that Trust has a significant positive effect on Customer Retention.

4) The results of the t test on the Complaint Handling variable showed t count of 2.890 with a probability of 0.005 , where the value is below $0.050 .005<0.05$. Thus, H4 is accepted, which means that Complaint Handling has a significant positive effect on Customer Retention.

5) The $t$ test results on the Facility variable showed $t$ count of 2.135 with a probability of 0.035 , where the value is below $0.050 .035<0.05$. Thus, H5 is accepted, which means that Facility has a significant positive effect on Customer Retention. 


\subsection{Discussion}

The Effect of Company Image, Customer Incentives, Trust, Complaint Handling, and Facilities on Customer Retention BMT Amanah Ummah Kartasura.

The test results showed that $F$ count is 16,001 with a probability of 0,000 , which value is below 0,000. This shows that all independent variables, Company Image, Customer Incentives, Trust, Complaint Handling, and Facilities have a significant effect simultaneously (together) on Customer Retention. These results prove that the higher the company image, customer incentives, trust, complaint handling, and facilities, the customer retention will increase significantly.

\section{The Effect of Company Image on Customer Retention BMT Amanah Ummah Kartasura.}

The $t$ test results on the Company Image variable obtained t count of 1.740 with a probability of 0.173 , which value is above $0.050 .173>0.05$. Thus, H1 is rejected, which means that there is no significant positive effect partially Company Image on Customer Retention. The result of this study is different from the research by Neupane (2020) which proves that brand image has a significant positive effect on customer loyalty intention in an organization.

\section{The Effect of Customer Incentives on Customer Retention BMT Amanah Ummah Kartasura.}

The results of the $t$ test on the Customer Incentive variable obtained $t$ count of 0.953 with a probability of 0.085 whose value is above $0.050 .085>0.05$. Thus, $\mathrm{H} 2$ is rejected, which means that there is no significant positive effect partially Customer Incentives on Customer Retention. This study is different from with previous research conducted by Noviandari, Retnowati and Firmanzah (2012) where customer incentives have a positive and significant effect on customer retention. The incentives that are given will be of added value to the company since the incentives will allow members to survive for a long time and be loyal to the company. Nevertheless, at a time when consumers have more choices than ever before, the right incentive program can direct consumers to a brand, make them feel like a valued customer, and turn them into loyalists and brand advocates. In fact, customers participate heavily in loyalty, reward, and points programs, and 50 percent report these programs as driving their buying behavior.

The Effect of Trust on Customer Retention BMT Amanah Ummah Kartasura.

The results of the $t$ test on the Trust variable obtained $t$ count of 6.409 with a probability of 0.000 , which value is below $0.050 .000<0.05$. Thus, H3 is accepted, which means that partially, there is a significant positive effect of Trust on Customer Retention. This result is in line with previous research conducted by Septrizola, Evanita, and Nanda (2019). Trust has a positive and significant effect on customer retention. This study is similar to the previous research conducted by Septrizola, Evanita, and Nanda (2019). Trust has a positive and significant effect on customer retention. Trust can show that there is a good system in the company and trust given by consumers is one of the initial keys where the goals set by the 
company will be achieved. One of the important things that every company needs to do and pay attention to is to retain existing customers, continue to work with new potential customers so that customers don't leave the company to become customers of other companies. In other words, the company must be able to maintain customer retention. The trust that customers have in the product or service brands sold by the company can build consumer retention.

\section{The Effect of Complaint Handling on Customer Retention BMT Amanah Ummah Kartasura.}

The results of the $t$ test on the Complaint Handling variable obtained t count of 2.890 with a probability of 0.005 , which value is below $0.050 .005<0.05$. Thus, H4 is accepted, which means that partially, there is a significant positive effect of Complaint Handling on Customer Retention. This study is similar to the previous research conducted by Runtuwene, Pio and Lompoliuw (2019) that complaint handling has a positive and significant effect on customer retention. The relationship between complaint handling and customer retention is influenced by consumer experience, which makes complaints resolved properly, complaints from consumers can make the company better. Feedback submitted by customers arises because customers have complaints when the customer has a long-term relationship with the company (Bell and Ludington, 2006). A customer usually provides direct feedback in the form of information about complaints that customers have to the employees (Lovelock and Wirtz, 2007). Feedback provided by a customer can create development and improvement activities for products or services sold by the company (Haverila and Naumann, 2010).

\section{The Effect of Facility on Customer Retention BMT Amanah Ummah Kartasura.}

The results of the $t$ test on the Facility variable obtained $t$ count of 2.135 with a probability of 0.035 , which value is below $0.050 .035<0.05$. Thus, H5 is accepted, which means that partially, there is a significant positive effect of Facility on Customer Retention. This result is in line with the research by Nurcahyo (2017), where facilities have a positive and significant effect on customer loyalty. This shows that bad facilities will lead to bad customer satisfaction. This means that better facilities will also increase the level of customer satisfaction and then build customer retention.

\section{Conclusion and Suggestion}

\subsection{Conclusion}

Referring to the results of the analysis and previous discussions regarding the effect of Corporate Image, Customer Incentives, Trust, Complaint Handling, and Facility on Customer Retention, it can be concluded as follows.

a. Simultaneously (together) Company Image, Customer Incentives, Trust, Complain Handling, and Facilities have a significant effect on Customer Retention of BMT Amanah Ummah Kartasura.

b. Partially, Company Image has no significant effect on Customer Retention of BMT Amanah Ummah Kartasura.

c. Partially, Customer Incentives has no significant effect on Consumer Retention of BMT 
Amanah Ummah Kartasura.

d. Partially, Trust has a significant effect on Customer Retention BMT Amanah Ummah Kartasura.

e. Partially, Complaint Handling has a significant effect on Customer Retention of BMT Amanah Ummah Kartasura.

f. Partially, Facility has no a significant effect on Customer Retention of BMT Amanah Ummah Kartasura.

\subsection{Suggestion}

From the results of this study, the researcher provides several suggestions, as follows:

a. BMT Amanah Ummah in Kartasura must be able to put forward its company image in order to build customer retention.

b. Customer incentives are needed to help the organization or institution to make the emotional connections with consumers, and it is also necessary to make free marketing innovations, such as new product offerings.

c. BMT Amanah Ummah Kartasura can increase the variables of facility and complaint handling to customers.

\section{References}

Arikunto, S. (2012). Prosedur Penelitian.Jakarta:n Rineka Cipta.

Fukuyama, F. (1995). Trust. New York: The Free Press.

Gerson, R.F. (2004). Measuring Customer Satisfaction. Jakarta: PPM.

Haefner, J. E., Deli-Gray, Z., \& Rosenbloom, A. (2011), “The importance of brand liking and brand trust in consumer decision making: Insights from Bulgarian and Hungarian consumers during the global economic crisis", Managing Global Transitions: International Research Journal, Vol. 9 No.3, pp.249-273.

Hafeez, S., \& Hasnu, S. (2010), "Customer satisfaction for cellular phone in Pakistan: A case study of Mobilink", Business and Economics Research Journal, Vol.1 No.(3), pp. 3544.

Hafeez, S. and Muhammad, B. (2012), “The Impact of Service Quality, Customer Satisfaction and Loyalty Programs on Customer's Loyalty: Evidence from Banking Sector of Pakistan”, International Journal of Business and Social Science ,Vol.3 No.16, pp. 200209.

Heriyadi, Listiana, E. dan Lay, Y.N. (2018). An Analysis of the Influence of Service Quality, Personal Selling and Complaint Handling and Trust on Customer Retention (Survey of Bank Harda International Savings Customers, Pontianak Branch). Volume 7 Number 2.

Kotler.P. (2008). Marketing Principles 2. Twelfth Edition. Jakarta : Erlangga.

Kotler.P. dan Keller.L.K. (2009). Marketing Management. Jakarta : Erlangga.

Kotler, Philip and Kevin Lane Keller. (2012). Marketing Management. Issue 13 Volume 1 and 2. Jakarta: Erlangga. 
Kotler, Philip dan Keller, Kevin Lane (2012) "Marketing Management" Volume 123 Edition. Erlangga, Jakarta.

Krismawintari, D.P.N., dan Kurniawati, E.S.N. (2018). The Influence of Relational Marketing on Customer Satisfaction and Customer Retention at Angelo Store Ubud Bali Herbal. Volume 13 Number 1.

Ling, C.K., Nasab, A.S., dan Danesh, N.S. (2012). The Study of Customer Satisfaction, Customer Trust and Switching Barriers on Customer Retention in Malaysia Hypermarkets. International Journal of Business and Management Volume 7 Number 7 Page 141-150.

Lupiyoadi.R. (2014). Service Marketing Management. Edition 3. Jakarta. Jakarta: Salemba Empat.

Lupiyoadi (2013) “Service Marketing Management” Salemba Empat, Jakarta.

Nasution Muhammad Nur (2015) "Integrated Quality Management" 3rd Edition, Ghalia Indonesia, Bogor.

Noor Juliansyah (2015) "Research Methods, Undergraduate Thesis, Thesis, Dissertation, and Scientific Work Metode" Prenadamedia, Jakarta.

Ndubisi, O.N. (2012). Relationship quality antecedents : The Malaysian retail banking perspective. International Journal of Quality \& Reliability Management - September Volume 29 Number 6 Page 829-845.

Noviandari, I. Retnowati, N. dan Firmanzah, F. (2012). The Influence of Point Rewards, Lucky Draws and Insurance on Customer Loyalty of PT ISM Bogasari Flour Mills Surabaya. Branchmarck's Journal of Management. Volume 4. Pages 168-178.

Over Mexi \& Ratna Juwita (2017) “The Influence of Service Quality, Customer Satisfaction, Product Quality and Relationship Marketing (Case Study of Kopi Pulang Palembang Customers)".

Parno, Nursalim, E., dan Khairi. (2018). The Effect of Revenue Sharing and Giving Bonuses on Customer Loyalty at Bank Syariah Mandiri Sangatta Branch Office. International Journal Ihya'Ulum Al-Din Volume 20 Number 1 page 17-40.

Ramesh Neupane. (2015). The Effects of Brand Image on Customer Satisfaction And Loyalty Intention in Retail Super Market Chain UK. Greenwich London College, London. R. Neupane. (2015) Int. J. Soc. Sci. Manage. Vol-2, issue-1: 9-26 DOI: 10.3126/ijssm.v2i1.11814.

Rauf, Abdul dan Ismayudin Yulizer (2016) "Marketing Management" CV Artika Nawala, Jakarta.

Runtuwene, F.R., Pio, J.R., dan Lompoliu, M.S.T. (2019). Factors Affecting Customer Retention At PT. Erafone Mega Mall Manado. Journal of Business Administration Volume 9 Number 1 Pages 114-121.

Sangadji and Sopiah. Consumer behavior: A Practical Approach with the Association of Research Journals. Yogyakarta : Andi.

Septrizola, W., Evanita, S., dan Nanda, R. (2019). The Influence of Customer Satisfaction, 
Switching Barriers, and Customer Trust on Customer Retention of Sympathy Card Users in Padang State University Students. Journal of Management and Entrepreneurial Studies Volume 01 Number 01 Pages 207-217.

Soemirat, Soleh \& Ardianto, Elvinaro. (2007), Dasar-Dasar Public Relation. Cetakan kelima, Bandung : Penerbit PT. Remaja Rosdakarya.

Suchaeri, H. (2012). Total Customer: Profit Acceleration of All Time. Solo: Metamograf. Sugiyono. (2016). Metode Penelitian Kuantitatif, Kualitatif dan R\&D. Bandung: PT Alfabet.

Sunarti., Suyadi, I., dan Qonitat, N.N. (2018). The Influence of Customer Satisfaction, Switching Barrier and Brand Trust on Customer Retention (Survey on Undergraduate Students of Universitas Brawijaya Malang Customers of Wardah Brand Products). Journal of Business Administration (JAB) Volume 55 Number 2 Pages 57-67.

Tjiptono. F. (2011). Complaint Management (Complaints). Yogyakarta: Andi.

Turban, E. David King. Jae Lee. Ting-Peng. And Decorrah C. Turban (2010). Electronic commerce. Managerial perspective global. Edition (6 edistion). New Jersey: Pearson.

Widiartanto,. Farida, N. dan Sulistiani, F. (2015). The Effect of Trust, Commitment and Communication on Customer Retention with Customer Satisfaction as an Intervening Variable. Diponegoro Journal of Social and Political of Science.

Zulkifli, (2012). Relationship Marketing to Customer Retention and Customer Loyalty to Customers of Bank Mega, Tbk. Poor. Journal of Accounting and Management Volume 1 Number 1 Pages 55-68.

knks.go.id/berita/89/strategi-knks-untuk-tingkatkan-ekonomi-syariah-indonesia?category=1 